\title{
Key Plant, Key Pests: Pine Species (Pinus sp.) ${ }^{1}$
}

\author{
Juanita Popenoe, Jacqueline Bourdon, Caroline R. Warwick, and Chris Marble ${ }^{2}$
}

\section{Key Plant: Pine Species (Pinus sp.)}

Pine species (Pinus sp.) are evergreen trees with long, needle-like leaves. These needles are usually bundled together in groups of two or more in what is called a fascicle. Pines usually reach heights of 80 to 100 feet (25-30 $\mathrm{m})$. Mature bark is usually thick, growing in long, dark, sometimes orange-brown plates, except for the spruce pine (Pinus glabra) and the sand pine (Pinus clausa). These can have a much smoother, lighter bark. Seven native pines can be found throughout various ecosystems in Florida, and each one is best adapted to specific growing conditions ranging from dry sandhills to poorly drained flatwoods. Pinus sp. are one of the most common tree-types in the United States, particularly the more arid western US, and can be found in USDA hardiness zones 4 through 9. Many different species are available in the nursery trade for planting in landscapes as ornamentals, habitat restoration, or for use in timber production.

Pine trees are gymnosperms, so rather than fruiting or flowering, they produce seeds through cones. Both male and female cones are present on the same plant. While some species open their cones after several years, others may keep their cones past maturity and open in response to a fire event. Pines are an integral part of Florida's natural ecosystem and provide many resources for wildlife and people alike (Florida Forestry Information n.d.).

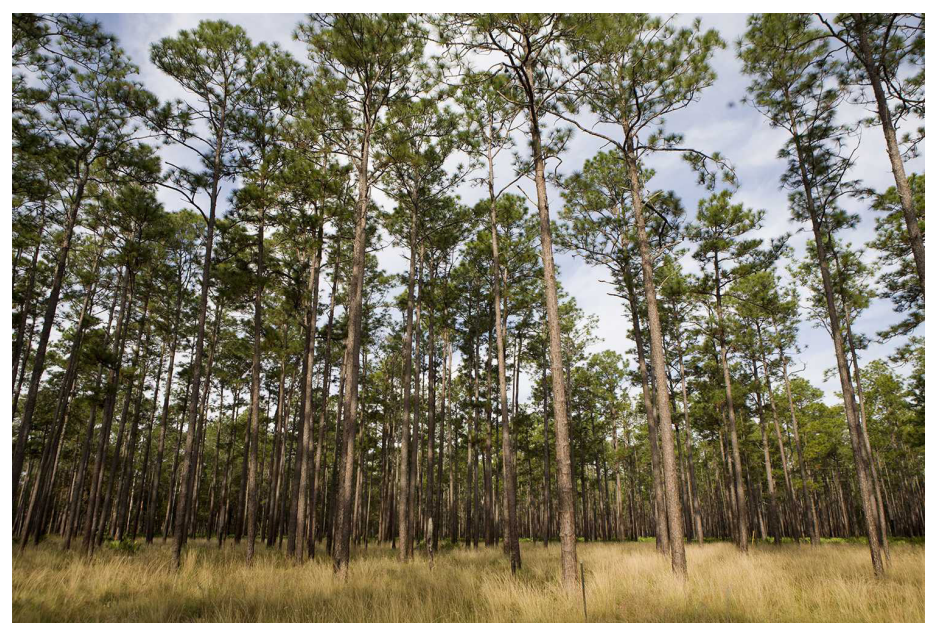

Figure 1. Mature Florida pine trees.

Credits: Tyler Jones, UF/IFAS

\section{Key Pests: Pine Species}

This series of Key Plant, Key Pests publications are designed for Florida gardeners, horticulturalists, and landscape professionals to help identify common pests associated with common Florida flora. This publication, the seventh in the Key Plant, Key Pests series, helps identify the most common pests found on Pinus sp.

This publication provides information and general management recommendations for borers, pine sawflies, pine bark beetles, pine tip moths, fusarium rust, pine chlorosis, and pitch canker. For a more comprehensive guide of woody ornamental insect management, download the current Professional Disease Management Guide for Ornamental

1. This document is ENH1301, one of a series of the Environmental Horticulture Department, UF/IFAS Extension. Original publication date October 2018. Visit the EDIS website at https://edis.ifas.ufl.edu for the currently supported version of this publication.

2. Juanita Popenoe, multi-county commercial fruit production agent IV; Jacqueline Bourdon, communications intern; Caroline Roper Warwick, science communications specialist; and Chris Marble, assistant professor; UF/IFAS Mid-Florida Research and Education Center, Apopka, FL 32703.

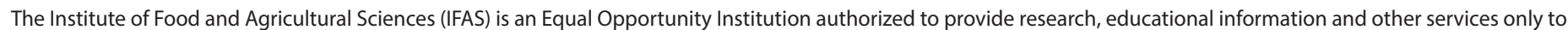

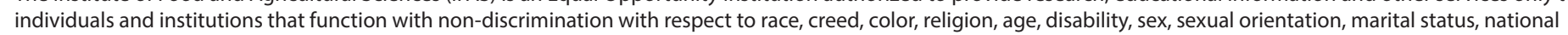
origin, political opinions or affiliations. For more information on obtaining other UF/IFAS Extension publications, contact your county's UF/IFAS Extension office. 
Plants or the Integrated Pest Management in the Commercial Ornamental Nursery Guide.

\section{Borers (Flathead Borers, Roundhead Borers) \\ RECOGNITION}

Borers are beetle larvae or caterpillars which eat their way into trees. There are many species within the borer class. Two of the more common species are flatheaded wood borer beetles (also known as metallic wood borers) and roundheaded wood borers (also known as longhorned beetles). Primary invaders can be found on healthy trees, while secondary invaders are found on stressed, dying, or dead trees. Look for branch wilt and dieback, holes, resin dripping on outer bark, frass under the bark, and/or boring dust caught in cracks of bark or at the base of tree.

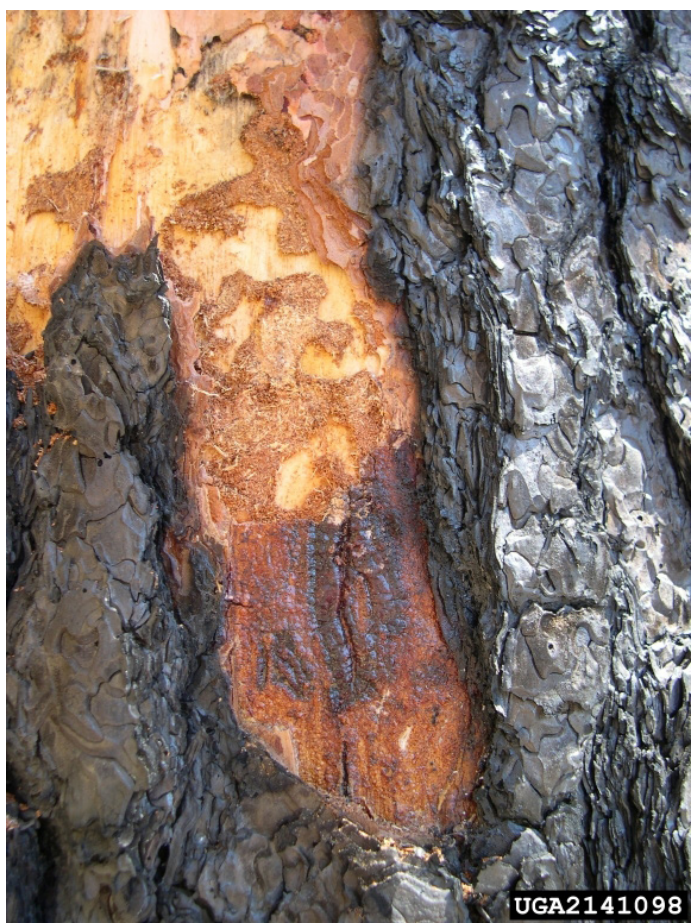

Figure 2. Damage caused by a metallic wood borer on a pine tree. Notice the larvae feeding at the bottom burn margin. Credits: Brytten Steed, USDA Forest Service, Bugwood.org

\section{CONTRIBUTING FACTORS}

Trees affected are generally weakened or wounded by some other predisposing factors such as root rot, soil disturbance due to construction, drought, flooding, senescence, or physical injuries to trunk or branches. Healthy trees are also at risk of hosting the pests.

\section{MANAGEMENT RECOMMENDATIONS}

Keep trees healthy to avoid infestations. Identify and remove highly susceptible trees and those with lethal infestations. Once infested, little can be done. Temporarily protect other nearby trees with approved insecticides applied on trunk from spring to fall according to label.

\section{Pine Sawflies (Neodipridon spp.) RECOGNITION}

Pine sawfly larvae look like caterpillars. They are up to 1 inch in length and have yellow to green bodies with variably patterned black dots or stripes. Large numbers of larvae feed on pine needles, leaving stubby remains with a tufted appearance. Adult females are 8-10 $\mathrm{mm}$ long, with stout light- to dark-brown bodies along with yellow-red-white markings. Adult males are 5-7 mm long with feathery antennae and can vary from light- to dark-brown bodies. Older foliage is consumed first, then younger foliage. Needles are eaten to stubs. A "bottle brush" appearance may occur in partially defoliated branches. Pine sawflies cause frass to accumulate on the ground under the tree.

\section{CONTRIBUTING FACTORS}

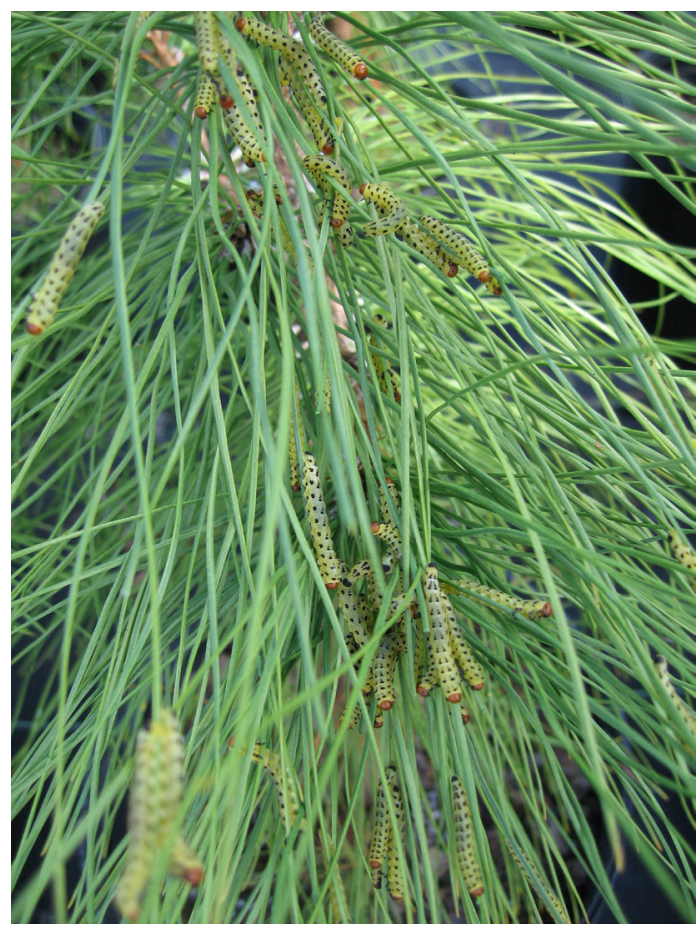

Figure 3. A group of blackheaded pine sawfly larvae feeding on a pine limb.

Credits: Juanita Popenoe, UF/IFAS

Sawfly populations are cyclical in nature and occur approximately at 8-10 year intervals. All pine species and ages of trees are susceptible.

\section{MANAGEMENT RECOMMENDATIONS}

Natural enemies and unfavorable weather usually keep sawfly populations at low levels. Promote tree vigor and health to aid in recovery from defoliation. Fully stock stands and promote early crown closure in pine plantations. 
Use of approved insecticides may be appropriate for high value trees when outbreaks occur. Watch out for bark beetles on defoliation-stressed trees (Dixon 2004).

\section{Pine Bark Beetles}

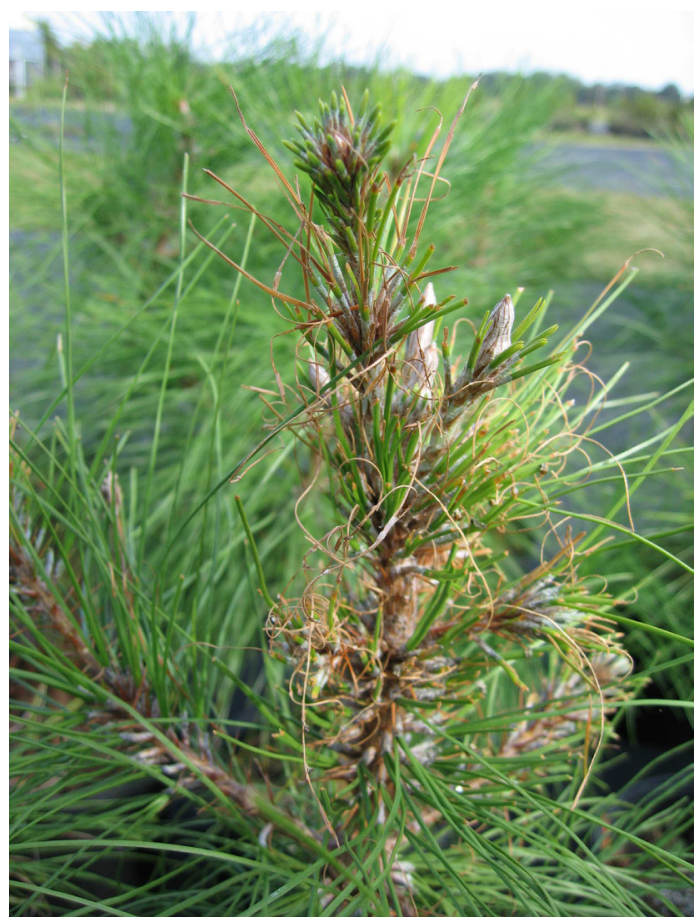

Figure 4. Pine sawfly damage on a pine tree.

Credits: Juanita Popenoe, UF/IFAS

\section{RECOGNITION}

There are 3 types of bark beetles in Florida: black turpentine beetle (BTB) (Dendroctonus terebrans (Olivier)), Ips engraver beetle (Ips spp.), and the Southern pine bark beetle (SPB) (Dendroctonus frontalis Zimmermann). Knowing the differences between these species and their impact is important. Adults bore through the outer bark and construct egg galleries in the inner bark. Immature offspring (larvae) continue tunnels, further disrupting phloem tissue. Ips and SPB also introduce a fungus that blocks water flow in the xylem. The entire tree canopy changes from green to yellow to orange/brown as damage progresses. By the time the color change begins to occur, it is too late to save the tree (Hulcr 2016).

\section{BLACK TURPENTINE BEETLE (Dendroctomus terebrans)}

This species is the largest bark beetle in the southeastern US, being 5-8 mm long. Adults have a dark red-brown to black cylindrical body and a convex head. Resin flow is located at the base of a tree (generally no higher than 8 feet). A conspicuous flow greater than 1 inch is present.
Trees can survive limited BTB attacks because they do not carry blue stain fungi (Mayfield, Hulcr, \& Foltz 2018).

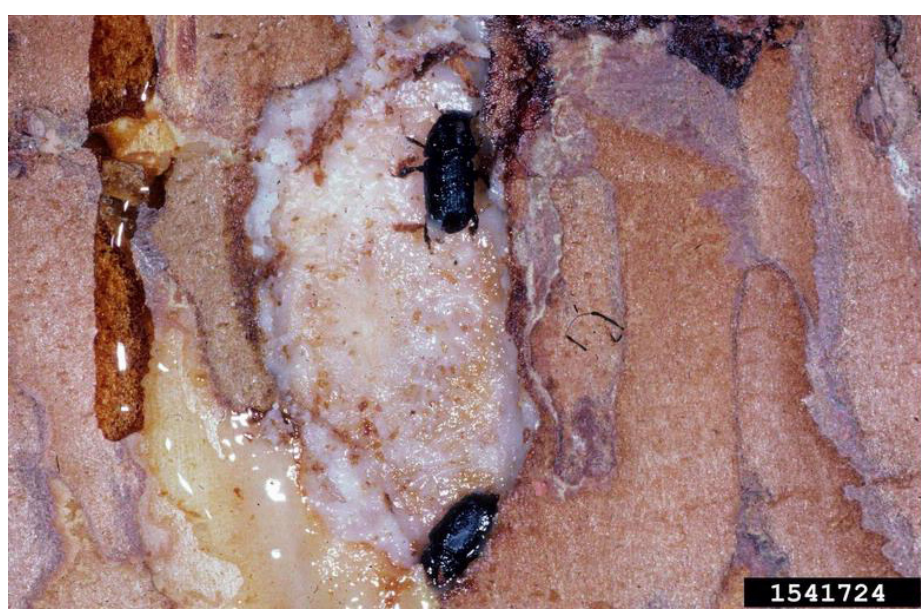

Figure 5. Adult black turpentine beetles.

Credits: Lacy L. Hyche, Auburn University, Bugwood.org

\section{IPS ENGRAVER BEETLE}

Adult Ips are 2-6 $\mathrm{mm}$ in length with a reddish-brown to black cylindrical body. Resin flows from many points along the trunk. Peeling back bark using a hatchet may reveal long vertical tunnels accompanied by smaller curved ones (Eickwort, Mayfield, \& Foltz 2015).

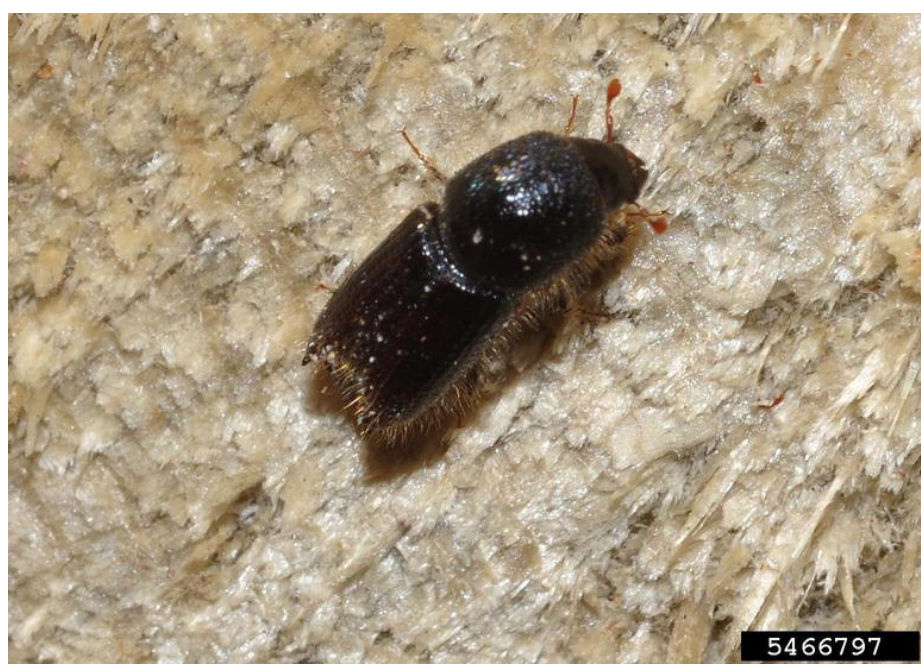

Figure 6. Adult Ips engraver beetle.

Credits: William M. Ciesla, Forest Health Management International, Bugwood.org

\section{SOUTHERN PINE BEETLE (SPB)}

Adults are 2-4 mm long with short legs and brown to black cylindrical bodies. Resin flows from many points along the trunk, with a popcorn-like shape of resin. These resin balls are located in between bark flakes rather than on top. Peeling off bark will reveal winding tunnels (Meeker et al. 2017). Photo: IPM 1669051, 2516004 


\section{CONTRIBUTING FACTORS}

Beetles are first attracted to weak, stressed and/or wounded trees; however, during outbreaks of SPB, healthy trees may be attacked. Drought, old age, disease, injury, fire, construction damage, lightning, etc. are common underlying causes of weak trees.

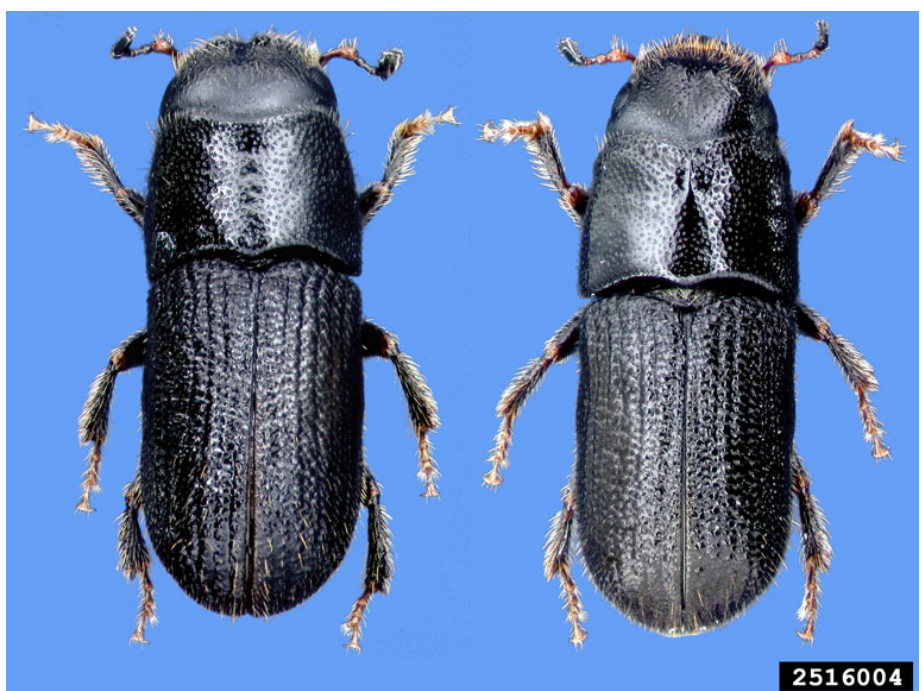

Figure 7. Adult southern pine beetles.

Credits: David T. Almquist, University of Florida, Bugwood.org

\section{MANAGEMENT RECOMMENDATIONS}

Promote tree health by minimizing tree stress. Avoid altering soil level and other practices causing root injury. Remove weak and/or infested trees or branches to prevent attracting beetles to the area. If beetles are known to be in the area, surrounding trees may benefit from a preventative insecticide application to the trunk. If an SPB attack occurs, remove affected trees immediately. SPB is the only beetle to cause an epidemic in Florida. Neighboring trees may need to be removed depending on the level of the outbreak.

\section{Pine Tip Moths (Rhyacionia sp.) RECOGNITION}

The two most common in Florida are the Nantucket tip moth (Rhyacionia frustrana) and the subtropical tip moth (Rhyacionia subtropica). Symptoms are discoloration of terminal growth, needle drop, dying tips, curled tips, webbing, and resin. Slash pine is most commonly attacked in central Florida. The adult moth emerges in the spring (Feb/March) and lays eggs on needles at branch tips. Larvae first feed on the needles, then bore into shoot tips, where pupation occurs. There are three to five generations per year (Dixon 2017).

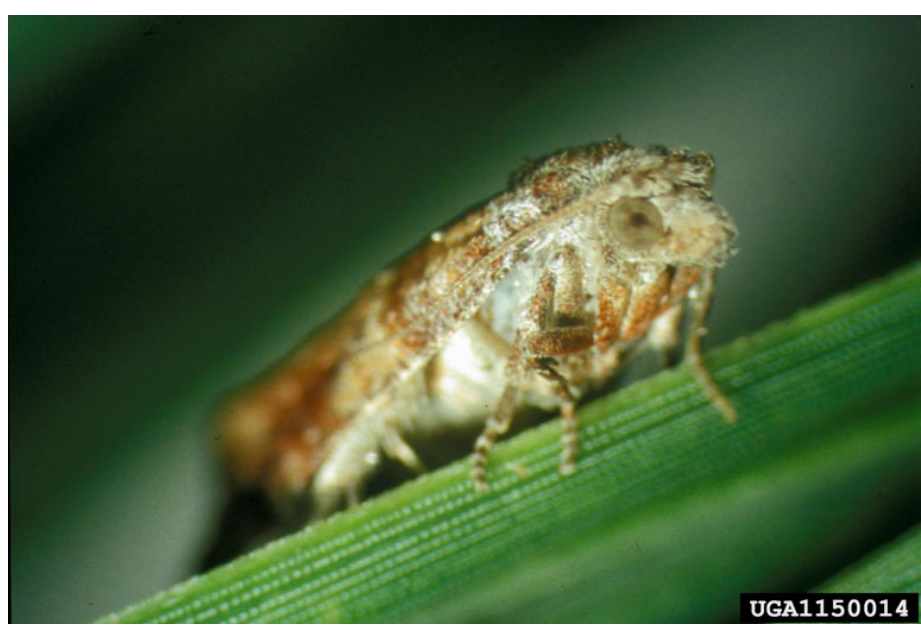

Figure 8. An adult Nantucket pine tip moth.

Credits: Christopher Asaro, University of Georgia, Bugwood.org

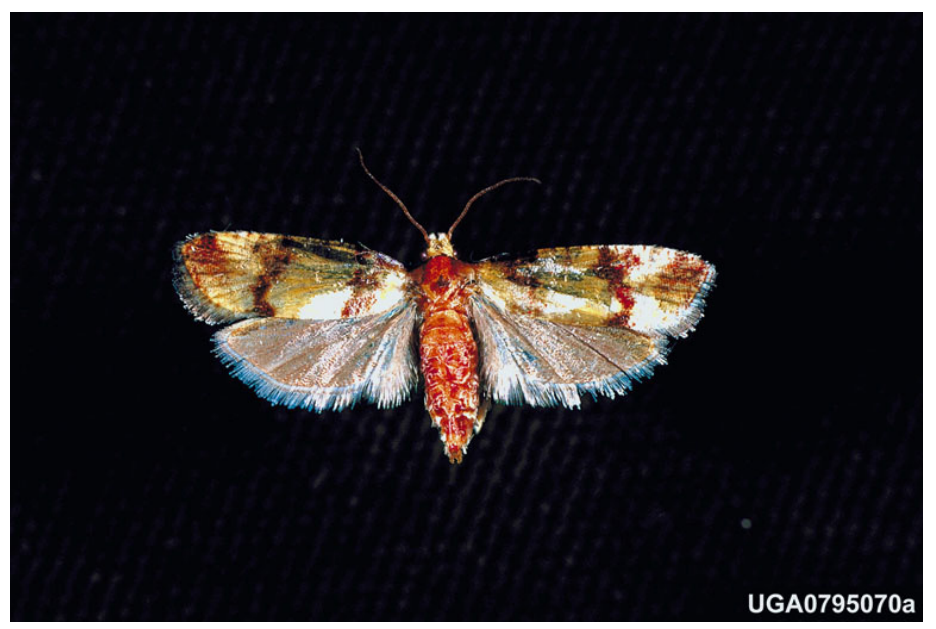

Figure 9. An adult subtropical pine tip moth.

Credits: Harry O. Yates III, USDA Forest Service, Bugwood.org

\section{CONTRIBUTING FACTORS}

Damage most frequently occurs on young trees less than 15 feet tall, possibly related to stress or weak growth. It is most common in loblolly pine (Pinus taeda L.).

\section{MANAGEMENT RECOMMENDATIONS}

Infestations cause predominantly aesthetic damage that trees usually outgrow. Tree mortality is rare. Encourage thrifty growth and natural enemies. Prune out and remove damaged tips. Use of approved systemic insecticides may be warranted on high value trees.

\section{Fusiform Rust (Cronartium quercuum f. sp. fusiforme) RECOGNITION}

Fusiform rust is a native disease caused by fungus that deforms and kills pines. Spindle-shaped galls form on branches or stems of loblolly or slash pines. Bright yellow blisters form in the spring and release orange spores which infect oaks. The organism must spend part of its life cycle 
on pines and part on oaks (laurel and water oaks are preferred). At the end of the summer, basidiospores are produced from oak infections, which then infect pines. Symptoms on oaks are inconspicuous yellow pustules and black telia on the undersides of leaves. Trunk galls can cause trunks to break in high winds (Demers et al. 2016).

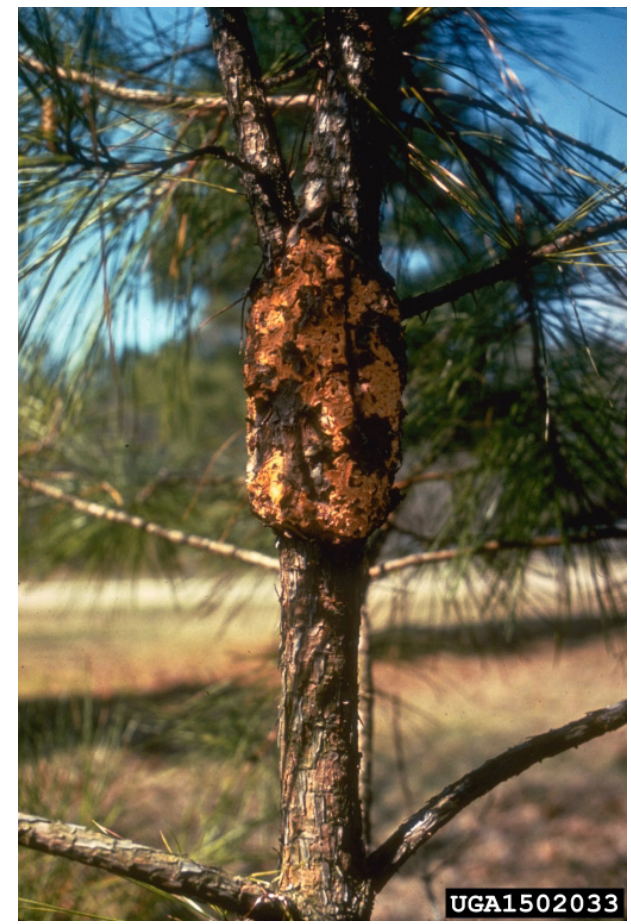

Figure 10. A pine displaying symptoms of the fruiting aecial stage of fusiform rust.

Credits: USDA Forest Service, Region 8, Southern, USDA Forest Service, Bugwood.org

\section{CONTRIBUTING FACTORS}

Both pines and oaks must be in the area for the organism to complete its life cycle. Outbreaks are favored in intensely managed young pine stands of loblolly and slash.

\section{MANAGEMENT RECOMMENDATIONS}

Prune branches several inches below the gall. Remove trees which have galls on trunks or main branches. If the area of infection exceeds 50\%, it may be best to clear cut pines. When planting new pines, be sure to steer clear of oaks, especially water oaks, which are a host for the fungus.

\section{Pine Chlorosis and Decline RECOGNITION}

Gradual yellowing of the foliage, thinning of the crowns, and/or dieback of pines is typical of pine chlorosis and decline. These symptoms usually occur in areas receiving high amounts of water and fertilizer.

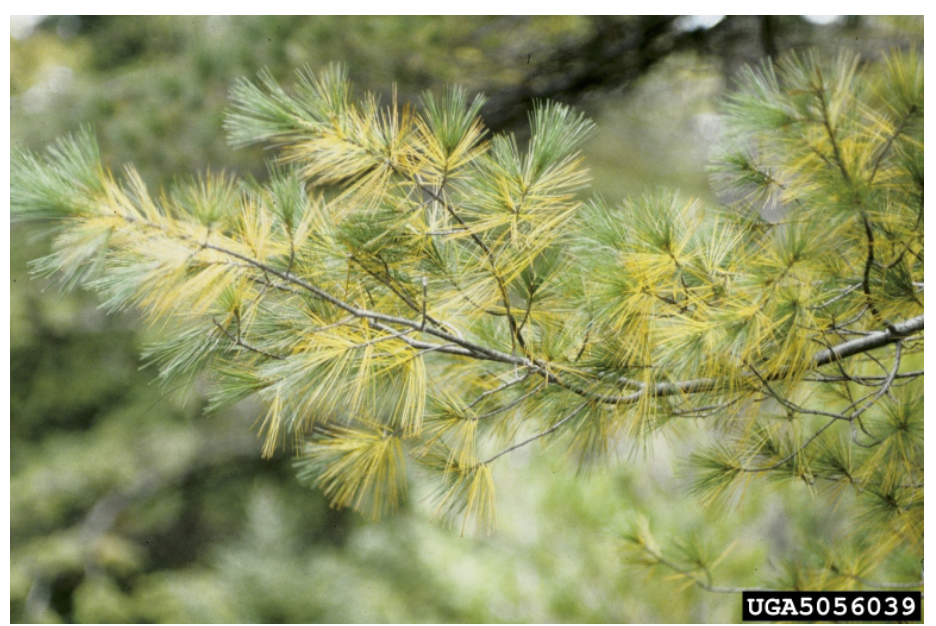

Figure 11. Eastern white pine showing signs of pine chlorosis. Credits: Joseph O'Brien, USDA Forest Service, Bugwood.org

\section{CONTRIBUTING FACTORS}

Intensive and disruptive management practices can be lethal to pines. Site disturbances, excessive water or fertilizer, and high $\mathrm{pH}$ are all contributing factors.

\section{MANAGEMENT RECOMMENDATIONS}

Keep maintenance activities away from pine stands. Mulch pine stands instead of having highly-maintained turf over their root zone. Direct irrigation spray away from pine trunks. Soil acidification, micronutrient applications, or tree injection may provide improvement in some cases. Where trees must be replaced, consider other tree species which can tolerate intensive site and maintenance conditions (Gilman and Watson 2014).

\section{Pitch Canker (Fusarium circinatum) RECOGNITION}

The fungus enters through an open wound in the pine bark and begins to feed on the woody tissues, which leads to the formation of a canker. Long lines of resin begin seeping out of the cankers, and diseased tissue becomes soaked with resin. Needles become brown and entire branches begin to die off. Pines show "flagging" of dead branches (Hicks et al. 2011).

\section{CONTRIBUTING FACTORS}

Previous injury from insects, machinery, lightning, or wind damage leave an open lesion for spores to germinate in. Areas that receive high nitrogen treatments may cause crown die-back from shading due to increasing competition, leaving wounds for the fungus to invade. Canker can occur in any pine species but is especially prevalent in slash pine. 


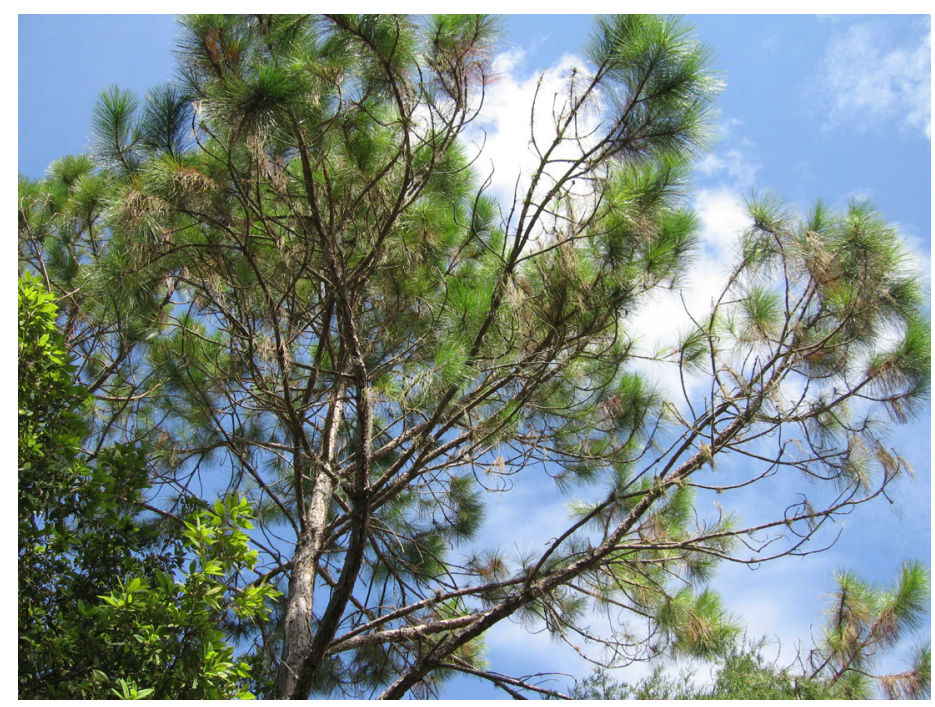

Figure 12. Symptoms of Fusarium circinatum on pine canopy. Credits: Juanita Popenoe, UF/IFAS

\section{MANAGEMENT RECOMMENDATIONS}

Remove trees showing signs of damage, as pruning has not been proven to slow the development of pitch canker in stands where the disease is well established. Fungicides with activity against pitch canker are available but have not been found effective in already-infested disease control.

\section{References}

Demers, C., M. Andreu, B. McGowan, A. Long, and J. Nowak. 2005. Thinning southern pines - A key to greater returns. SSFOR24. Gainesville: University of Florida Institute of Food and Agricultural Sciences. http://edis.ifas. ufl.edu/fr159

Dixon. W. N. 2003. "Nantucket pine tip moth, Rhyacionia frustrana (Comstock) (Insecta: Lepidoptera: Torticidae)." http://entnemdept.ufl.edu/creatures/trees/moths/nantucket_pine_tip_moth.htm

Dixon, W. N. 2004. "Pine sawflies, Neodiprion spp. (Insecta: Hymenoptera: Diprionidae).” http://entnemdept.ufl.edu/ creatures/trees/sawfly/pine_sawflies.htm

Eickward, J. M., A. E. Mayfield, and J. L. Foltz. 2006. Ips engraver beetles, Ips spp. (Insecta: Coleoptera: Curculionidae: Scolytinae). EENY-388. Gainesville: University of Florida Institute of Food and Agricultural Sciences. http://edis.ifas. ufl.edu/in701

Florida Forestry Information. n.d. "Pinaceae: The pine family." http://www.sfrc.ufl.edu/Extension/ffws/tfpin.htm
Gilman, E. F., and D. G. Watson. 1993. Pinus elliottii: Slash pine. ENH-622. Gainesville: University of Florida Institute of Food and Agricultural Sciences. http://edis.ifas.ufl.edu/ st463

Hicks, S. L., M. C. Monroe, G. S. Iyer, and J. A. Smith. 2011. What is a healthy forest? A supplement to Florida project learning tree. FOR286. Gainesville: University of Florida Institute of Food and Agricultural Sciences. http://edis.ifas. ufl.edu/fr354

Hulcr, J. 2016. My pine is under attack - What should I do? FOR331. Gainesville: University of Florida Institute of Food and Agricultural Sciences. http://edis.ifas.ufl.edu/fr399

Mayfield, A. E., J. Hulcr, and J. L. Foltz. 2005. Black turpentine beetle, Dendroctonus terebrans (Olivier) (Insecta: Coleoptera: Curculionidae: Scolytinae). EENY356. Gainesville: University of Florida Institute of Food and Agricultural Sciences. http://edis.ifas.ufl.edu/in636

Meeker, J. R., W. N. Dixon, J. L. Foltz, and T. R. Fasulo. 2000. Southern pine beetle, Dendroctonus frontails Zimmerman (Insecta: Coleoptera: Curculiondae: Scolytinae). EENY176. Gainesville: University of Florida Institute of Food and Agricultural Sciences. http://edis.ifas.ufl.edu/in333 